\title{
p53 Tumour suppressor gene expression in pancreatic neuroendocrine tumour cells
}

\author{
C Bartz, C Ziske, B Wiedenmann, K Moelling
}

\begin{abstract}
Neuroendocrine pancreatic tumours grow slower and metastasise later than ductal and acinar carcinomas. The expression of the p53 tumour suppressor gene in pancreatic neuroendocrine tumour cells is unknown. Pancreatic neuroendocrine cell lines $(n=5)$ and human tumour tissues $(n=19)$ were studied for changed p53 coding sequence, transcription, and translation. Proliferative activity of tumour cells was determined analysing Ki-67 expression. No mutation in the p53 nucleotide sequence of neuroendocrine tumour cell was found. However, an overexpression of p53 could be detected in neuroendocrine pancreatic tumour cell lines at a protein level. As no p53 mutations were seen, it is suggested that post-translational events can also lead to an overexpression of p53. (Gut 1996; 38: 403-409)
\end{abstract}

Keywords: pancreatic tumour, tumour suppressor gene.

Carcinomas of the pancreas are common forms of cancer in the gastroenteropancreatic system. They can be classified according to their morphological and functional characteristics. The non-neuroendocrine pancreatic carcinomas are mainly of ductal origin accounting for over $90 \%$ of all pancreatic tumours. Among other rare neoplasms (for example, giant cell and epidermoid carcinomas, lymphomas, cystadenocarcinomas, etc), carcinomas with acinar cell differentiation represent a distinct entity within pancreatic neoplasms with an overall frequency of about $1 \%$ of all pancreatic carcinomas. ${ }^{1-3}$ Recent studies showed that acinar tumours can even be subdivided whereby approximately one third of these tumours possess both neuroendocrine and exocrine features (amphicrine tumours). Neither amphicrine nor pure exocrine acinar carcinomas showed immunoreactivity for the tumour suppressor gene p53.4 The residual $5 \%$ of all pancreatic neoplasmas are of islet cell or other neuroendocrine origin.

Neuroendocrine tumours of the pancreas (especially gastrinomas, VIPomas, and glucagonomas) are malignant in about $60 \%$ of cases. Half of these tumours are clinically functional that is, they exhibit an endocrine activity (secreting insulin, gastrin, vasoactive intestinal polypeptide, glucagon, pancreatic polypeptide, etc) - whereas the other half of these tumours does not cause endocrine symptoms. ${ }^{5}$

Based on their growth and metastatic rate, pancreatic carcinomas can be clinically divided into two groups, neuroendocrine and non-neuroendocrine metastatic tumours. In contrast, non-neuroendocrine carcinomas exhibit clearly faster growth along with a higher metastatic potential.

In various neoplasms of the gastroenteropancreatic system the expression of the p53 tumour suppressor gene has been implied as an important factor for cell growth and has also been extensively investigated in a large number of other human tumours. ${ }^{6}$ The 53 $\mathrm{kDa}$ nuclear phosphoprotein encoded by 393 amino acids has often been found to be functionally inactivated by single point mutations occurring in $99 \%$ of the cases within four of five evolutionarily highly conserved domains. ${ }^{7}$ These point mutations generally lead to an extended half life caused by protein stabilisation and conformational changes inhibiting the normal function of the protein. Other inactivating mechanisms for wild type p53 include changed protein phosphorylation and complex formation with mutant $\mathrm{p} 53$ protein, viral oncogene proteins, the mdm2-gene product or with members of the heat shock protein family, ${ }^{8-11}$ resulting in conformational changes and cytoplasmatic sequestration. p53 Has been implicated in the cellular response mechanisms to DNA damage and has been found to induce apoptosis in colon carcinoma cell lines. ${ }^{12} 13$

Similarly in ductal pancreatic carcinomas, a variety of p53 inactivating mutations have been found in cell lines and in tumour tissues. ${ }^{14-16}$

In contrast, acinar pancreatic carcinomas, resembling clinically and prognostically ductal carcinomas do not seem to contain mutated p53, ${ }^{4}$ suggesting that p53 mutations may not influence cellular proliferation. So far, neuroendocrine pancreatic tumours, known to proliferate slowly, have not been studied for changed expression and synthesis of $\mathrm{p} 53$.

We investigated a variety of neuroendocrine pancreatic tumour cell lines for p53 point mutations, as well as the level of mRNA and protein. In parallel, tissue specimens $(n=19)$ were tested for $\mathrm{p} 53$ immunoreactivity.

\section{Methods}

\section{Cell lines and tumour samples}

The following pancreatic neuroendocrine cell lines were used: Bon, ${ }^{17}$ QGP1, ${ }^{18}$ AR42J, ${ }^{19}$ RIN 38, ${ }^{20}$ and InR 1G9. ${ }^{21}$ Pancreatic ductal cell lines Capan 1 and Capan2, ${ }^{22}$ DanG, ${ }^{23}$ and Panc1 $^{24}$ as well as the hepatoma cell lines HepG $2,{ }^{25}$ Huh7, ${ }^{26}$ and PLC/PRF/5 27 and the rat pheochromocytoma cell line PC $12^{28}$ served as controls. 
TABLE I Oligodeoxynucleotides used for PCR amplification of p53 sequences of genomic and complementary DNA

\begin{tabular}{|c|c|c|c|c|c|}
\hline $\begin{array}{l}\text { Primer } \\
\text { number }\end{array}$ & Primer sequence & $\begin{array}{l}\text { Length of } \\
\text { amplificate }\end{array}$ & Intron & Exon & Intron \\
\hline \multirow{6}{*}{$\begin{array}{l}3696 \\
3697 \\
3130 \\
3128 \\
3488 \\
3489 \\
3129 \\
3127\end{array}$} & \multirow{6}{*}{$\begin{array}{l}\text { TTC CTC TTC CTG CAG TAC TC } \\
\text { ACC CTG GGC AAC CAG CCC TGT } \\
\text { ACA GGG CTG GTT GCC AGG GT } \\
\text { AGT TGC AAA CCA GAC CTC AG } \\
\text { GTG TGG TCT CCT AGG TTG GC } \\
\text { GTC AGA GGC AAG CAG AGG CT } \\
\text { TAT CCT GAG TAG TGG TAA TC } \\
\text { AAG TGA ATC TGA GGC ATA AC }\end{array}$} & & \multirow{6}{*}{$\begin{array}{l}\text { (4) } 15 \\
\text { (6) } 14 \\
\text { (7) } 12\end{array}$} & (5) $376-380$ & \multirow{6}{*}{$\begin{array}{l}\text { (5) } 26-46^{\star} \\
\text { (6) } 15 \\
\text { (5) } 26-46^{\star} \\
\text { (7) } 45-65^{\star} \\
\text { (8) } 47-67^{\star}\end{array}$} \\
\hline & & 245 & & (6) $668-672$ & \\
\hline & & 183 & & & \\
\hline & & 100 & & (7) $673-678$ & \\
\hline & & 189 & & (8) $783-791$ & \\
\hline & & 213 & & & \\
\hline $\begin{array}{l}4165 \\
4164\end{array}$ & $\begin{array}{l}\text { CAG AAA ACC TAC CAG GGC AGC } \\
\text { TGC TCG CTT AGT GCT CCC TGG }\end{array}$ & 621 & & $\begin{array}{l}\text { (4) } 298-318 \\
(8 / 9) 901-921\end{array}$ & \\
\hline $\begin{array}{l}9585 \\
9586\end{array}$ & $\begin{array}{l}\text { ACC AAG GCA ACT ATG GCT TCC } \\
\text { GTG CTC TCT TTG CAC TCC CTG }\end{array}$ & 615 & & $\begin{array}{l}\text { (4) } 302-322 \\
\text { (8) } 896-916\end{array}$ & \\
\hline
\end{tabular}

Numbers for primer pairs were arbitrarily chosen. The number in brackets given above refers to the specific intron or exon number. In case of exons, the number of coding nucleotides is given. In the case of introns the number of primer nucleotides of the primers chosen within the intron is given. With the exception of the last two sequences, which correspond to rat cDNA, all other sequences are human. Only the last four sequences given correspond to cDNA but not genomic DNA. ${ }^{*}$ Shows that the primer is completely positioned within the respective intron. Numbers given refer to the exons of the last proceeding coding nucleotide. The relative position of the oligodeoxynucleotides chosen is shown in Fig 1.

Tumour tissues studied included one gastrinoma, two insulinomas, one VIPoma, and 15 non-functional islet cell carcinomas as well as three hepatomas. They were either frozen, aceton fixed or paraffin wax embedded, formalin fixed.

\section{Antibodies}

Antibody CM1 raised in rabbits with recombinant wild type p53 was purchased from Medac, Hamburg, Germany. This antibody reacts with human and rodent p53. Antibody 1618 was raised in rabbits against a peptide comprising the $12 \mathrm{~N}$-terminal amino acids. This antibody reacts also with human and rodent p53. Murine, monoclonal antibody DO7 was obtained from Dianova, Hamburg, Germany. This antibody recognises amino acids $1-45$ of wild type p53 and is specific for human tissues and cells. Murine, monoclonal antibody pAb240 was obtained from Medac, Hamburg, Germany. This antibody reacts with amino acids $212-217$ of human mutant p53 or amino acids $206-211$ of mouse mutant p53.

Murine, monoclonal antibody pAb1801 was obtained from Medac, Hamburg, Germany. This antibody reacts with wild type human p53 and recognises the $\mathrm{N}$-terminal domain of $\mathrm{p} 53$. Antibody MiB1 was obtained from Dianova, Hamburg, Germany, and reacts with the fragment of wild type Ki67. The immunohistochemical staining was performed as previously described. ${ }^{29}$ For immunofluorescence microscopy a Texas-Red conjugated goat-antimouse-IgG, Dianova, Hamburg, Germany was used. To estimate the degree of the neuroendocrine cell proliferation, Ki67 labelling indices were determined by evaluation of 300 cells. Results are given in positively stained nuclei per 100 cells.

\section{$D N A$ and $R N A$ preparation and reverse \\ transcription}

Genomic DNA was prepared by proteinase K digestion followed by phenol/chloroform extraction according to standard protocols. ${ }^{30}$

Total RNA was obtained by the guanidinium-thiocyanate-method followed by a $\mathrm{CsCl}$-gradient centrifugation step essentially as already described. ${ }^{30}$ For cDNA analysis $5 \mu \mathrm{g}$ of total RNA were reverse transcribed using polymerase chain reaction (PCR) - buffer (see later), $2.5 \mu M$ random hexamer primer (Boehringer Mannheim, Mannheim, Germany), 200 U M-MLV-reverse transcriptase (Gibco BRL, Berlin, Germany), and $1 \mathrm{mM}$ dNTPs (Boehringer Mannheim, Mannheim, Germany). The dNTPs used for reverse transcription were sufficient for subsequent PCR.

\section{Oligodeoxynucleotides and PCR amplification procedure}

The oligodeoxynucleotides used for PCR and direct sequencing were synthesised on an Applied Biosystems (Weiterstadt, Germany) DNA synthesiser. Table I gives the sequences of the oligodeoxynucleotides used for PCR.

PCR amplification was performed on a Biomed Thermocycler 60 (Theres, Germany) and consisted of 35 cycles of one minute at $92^{\circ} \mathrm{C}$ denaturation, one minute 30 seconds annealing, and two minute 30 seconds at $72^{\circ} \mathrm{C}$ extension. The amplification was preceded initially with a five minute $92^{\circ} \mathrm{C}$ denaturation step and followed by a 10 minute $72^{\circ} \mathrm{C}$ extension step. Annealing temperatures were $61^{\circ} \mathrm{C}$ for cDNA, $60^{\circ} \mathrm{C}$ for Exon $5-7$, and $58^{\circ} \mathrm{C}$ for Exon 8. We used 2.5 U Taq-Polymerase (Promega, Heidelberg, Germany), the supplied reaction buffer, $0.5 \mathrm{mM}$ of each primer, and $150 \mu \mathrm{M}$ dNTPs in a $100 \mu$ reaction volume.

The amplificate was resolved on a $1 \%$ agarose-TRIS-borate-EDTA-gel, visualised by ethidium bromide staining and photographed. ${ }^{30}$ Bands corresponding to the expected size were excised, eluted using the IQIAEX-kit (Diagen, Hilden, Germany). In general $20 \%$ of the resulting eluate was sufficient to perform direct sequencing.

\section{Sequencing protocol}

Sequencing by the method of Sanger was performed using the Sequenase $2.0 \mathrm{Kit}$ (USB, Darmstadt, Germany and [ $\left.{ }^{35} \mathrm{~S}\right]$-dATP (Amersham, Braunschweig, Germany) according to the protocol proposed by Thein. ${ }^{31}$ The 


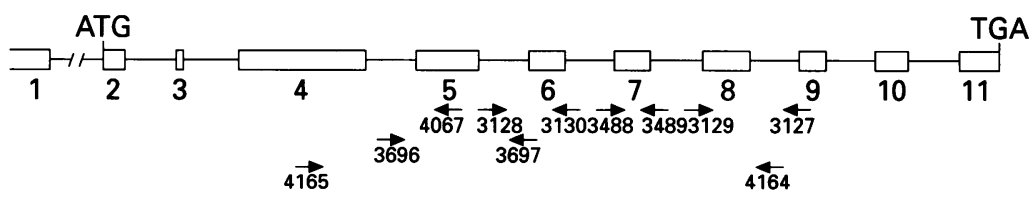

Figure 1: Position of oligodeoxynucleotides within the $p 53$ gene used for PCR analysis on human samples; note that the oligodeoxynucleotide 4164 spans the intron between the exons 8 and 9.

sequencing primers were identical to those used for PCR amplification.

\section{Northern blotting}

mRNA was analysed by northern blotting using $20 \mu \mathrm{g}$ of denatured total RNA separated on a formaldehyde-agarose-gel and transferred to a nylon membrane (Gene Screen, DuPoint, Bad Homburg, Germany) by SSC mediated diffusion blot. pC53SN3 containing human wild type p53 cDNA was a kind gift from A Teresky, Princeton, NJ, USA. The BamHIfragment of pC53SN3 was used to hybridise to human mRNA and the XhoI/SstII-fragment of p1 1-4 $4^{32}$ (kind gift from J Martinez, Princeton, NJ, USA) for murine mRNA. DNA probes were radioactively end labelled with [32P]dCTP (Amersham, Braunschweig, Germany) using the multiprime DNA labelling kit (Amersham, Braunschweig, Germany) according to the manufacturer's instructions. Hybridisation was done at $58^{\circ} \mathrm{C}$ following the procedure described by Bouwmester et al. ${ }^{33}$

\section{Immunoprecipitation and western blotting}

Radioactive cellular lysates were prepared by metabolic labelling of subconfluent $100 \mathrm{~mm}$ dishes of the described cell lines using $200 \mathrm{mCi}$ $\alpha-\left[{ }^{35} \mathrm{~S}\right]-$ methionine (Amersham, Braunschweig, Germany). Cells were lysed under RIPA conditions, ${ }^{30}$ cleared by centrifugation, and comparable amounts of protein as determined by liquid scintillation were incubated at $40^{\circ} \mathrm{C}$ with $15 \mathrm{ml}$ protein A-sepharose beads to which $3 \mathrm{ml}$ of purified monoclonal antibody or $5 \mathrm{ml}$ rabbit antiserum have been coupled previously. Intensive washing steps were included. The coupled protein was then separated by
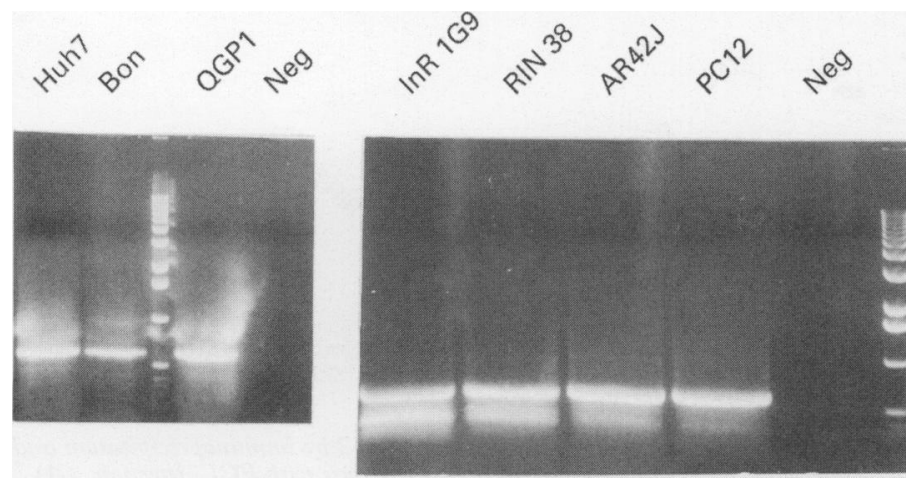

Figure 2: Analysis of amplified p53 cDNA of pancreatic cell lines. Analysis of amplified p53 cDNA on a preparative $1 \%$ agarose gel after reverse transcription of $5 \mu \mathrm{g}$ total $R N A$ and 35 cycles of PCR. The cell lines are given on the top. The numbers on the right correspond to base pairs (bp) of a marker. Negative control reaction does not contain any DNA except oligodeoxynucleotides. Oligodeoxynucleotides 4164 and 4165 were used to amplify human p53 cDNA, oligodeoxynucleotides 9585 and 9586 (not listed in Fig 1) for amplification of rat and hamster cDNA. The total reaction volume was loaded onto the gel (for details see Methods).
SDS-PAGE on a $10 \%$ gel. Subsequently the gel was dried and exposed to a film ( $X$ Ray, Kodak, Berlin, Germany). ${ }^{14}$ C-labelled molecular weight standards were purchased from Amersham, Braunschweig, Germany. For nonradioactive protein detection, comparable amounts (matched by cell counting) of total protein from centrifugation cleared cellular lysates were subjected to immunoprecipitation as already described, separated by SDS-PAGE, transferred to nitrocellulose (Schleicher and Schüll, Dassel, Germany) by electroblotting and then treated according to the manufacturer's instructions (ECL-Western blotting kit, Amersham, Braunschweig, Germany).

\section{Results}

In gastroenteropancreatic cancer, especially in pancreatic carcinomas, almost all the inactivating p53 mutations have been detected within four of five evolutionarily highly conserved domains corresponding to exons 4 to 8 . Therefore, PCR mediated amplification of a $621 \mathrm{bp}$ fragment of human cDNA (615 bp for murine cDNA) spanning these exons was chosen. In addition, primer sets for amplification of exons 5 to 8 of genomic DNA were designed and localised to the neighbouring introns (Fig 1 and Table II).

\section{Neuroendocrine pancreatic tumour cell lines do} not contain typical point mutations of $p 53$

Amplification of cDNA and genomic DNA resulted in a reaction product of the expected size for every cell line studied. Altered sizes suggesting major sequence changes were not seen. Figure 2 shows products of reverse transcribed and amplified DNA visualised on an ultraviolet screen. All neuroendocrine cell lines and the human hepatoma cell line Huh7 displayed a band of the correct size. This was also the case for genomic DNA amplifications (data not shown). Negative control samples (Neg) did not contain any template DNA. Direct sequencing of the amplified DNA fragments showed only one point mutation in each of the ductal pancreatic cell lines Pancl and Capan 1 as well as in the hepatoma cell line PLC. The mutations were found to be present in both alleles. For Panc1 the $\mathrm{G}$ to A exchange resulted in an Arg to His substitution at amino acid position 273 (Fig 3). The same base exchange was discovered in Capan 1 leading to Ala to Val substitution to codon 159. In PLC, a $G$ to $T$ base substitution replaced an Arg by a Ser at codon 249 (data not shown). This was not surprising as this codon is commonly mutated in human hepatocellular carcinoma. In contrast, none of the neuroendocrine cell lines displayed point mutations within the examined DNA sequences.

\section{Wild type protein $p 53$ varies in neuroendocrine} tumour cell lines

By northern blot analysis, a mRNA of an expected length of $2.8 \mathrm{~Kb}$ was found in all neuroendocrine cell lines (QGP1, InR 1G9, 


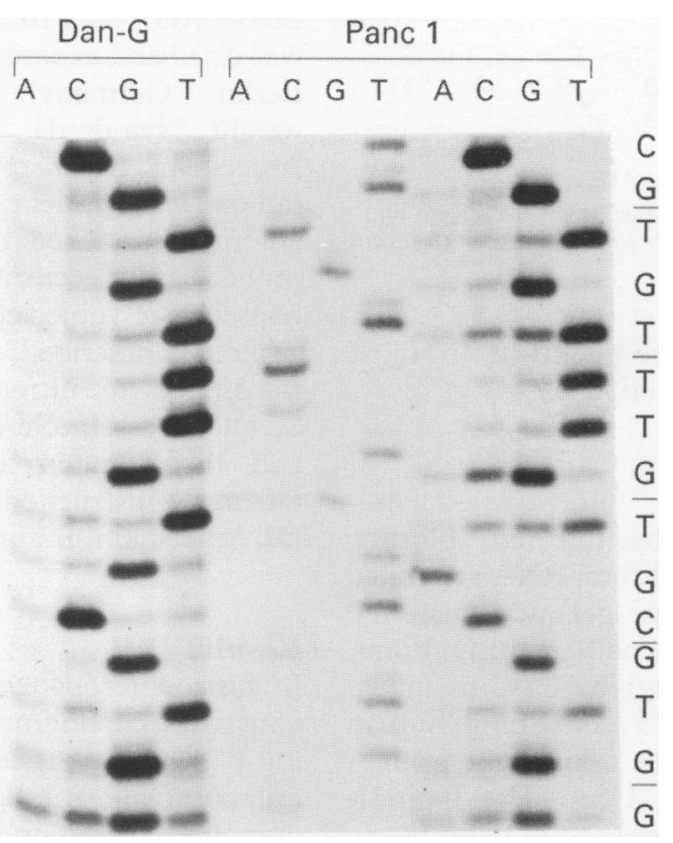

Figure 3: Identification of point mutations in pancreatic cell lines. Autoradiograph of a direct sequencing reaction of PCR amplified exon 8 (oligodeoxynucleotides 3127 and 3129) from genomic DNA of cell lines Dan-G and Panc1 (both strands). The p53 mutation of Panc1 showed a $G$ to A mutation corresponding to mutation from $\mathrm{Arg}$ to $\mathrm{His}$ at amino acid position 273. For comparison, the Dan- $G$ wild

RIN 38, AR42J, PC12). For the cell line Bon, a transcript was only detected by PCR amplification, but not by northern blotting. Transcripts of $2.8 \mathrm{~Kb}$ were also detected by northern blotting in the ductal pancreatic carcinoma cell lines Capan 1 and 2 . type sequence is shown.

Transcripts of DanG and Pancl were slightly larger in size (roughly $3.2 \mathrm{~Kb}$, data not shown).

To investigate whether the observed changes found so far had an influence on p53 protein expression, we performed metabolic labelling with $\left[\alpha^{35} S\right]$-methionine followed by immunoprecipitation (Fig 4). All cell lines showed an immunoprecipitate of $\mathrm{M}_{\mathrm{r}}$ about $50 \mathrm{kDa}$ except for the cell line Bon. The p53 protein precipitated from the murine cell lines InR 1G9 and RIN 38 had a slightly lower apparent molecular weight $\left(M_{r}\right.$ about $\left.50 \mathrm{kDa}\right)$ whereas Capan 1 showed a protein of a larger molecular weight of about $56 \mathrm{kDa}$. Panc1 displayed an additional signal of an apparent molecular weight of 60 $\mathrm{kDa}$. Interestingly, the monoclonal antibody pAb 240 specific for the mutant p53 phenotype, failed to precipitate $\mathrm{p} 53$ from Huh7, whereas all other antibodies tested did (data not shown). This suggests that overexpression of p53 in this cell line is probably not due to mutations leading to conformational changes recognised by pAb 240 . Furthermore, we examined the cell lines by immunoprecipitation combined with western blotting using an enhanced chemoluminescence detection system (Fig 5). The neuroendocrine cell line QGP1 as well as the control cell lines Huh7 and PLC showed a detectable protein of the correct molecular weight using the polyclonal antiserum 1618 for precipitation and the monoclonal antibody pAb 1801 for detection (Fig 5A). In contrast, Bon as well as AR42J and PC12 gave no signal. Capan2 and DanG were also negative (data not shown). Using pAB 240 for precipitation and detection we were able to show a signal of the appropriate size for all

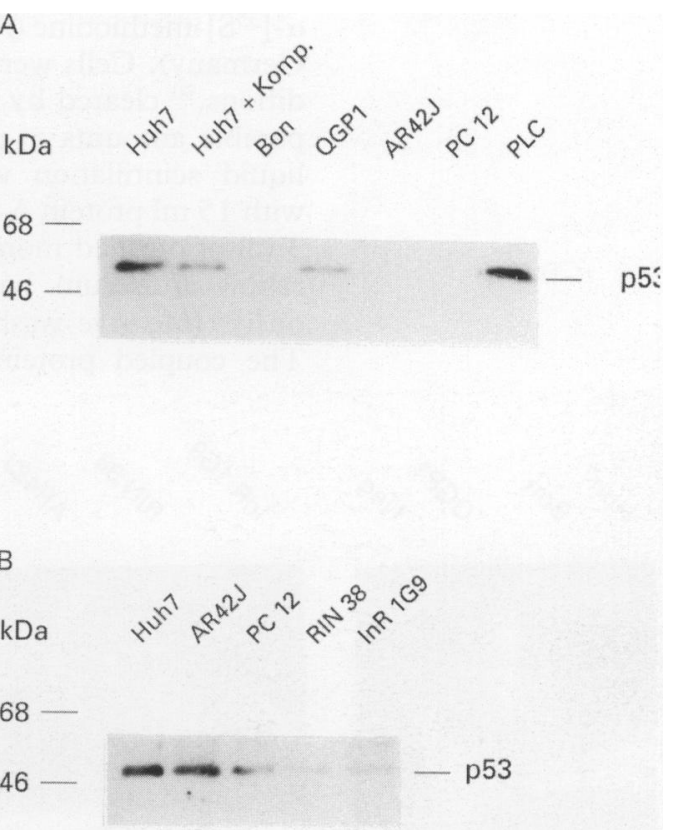

Figure 4: Immunoprecipitation of $p 53$ in various cell lines. Lysates prepared as described in Methods from

${ }^{55}$ SImethionine-labelled cells were immunoprecipitated with antibody CM1, directed against recombinant human p53, and separated on a $10 \%$ SDS-PAGE. Comparable amounts of protein were used as determined by scintillation counting. In lane 11, Huh7 lysate has been incubated without antibody $C M 1$ as a control. $p 53$ Which varies in size around the indicated p 53 marker is detectable in both neuroendocrine and ductal cell lines. Standard ${ }^{14} \mathrm{C}$ marker proteins were used (Amersham).
Figure 5: Identification of $p 53$ by immunoprecipitation and For precipitation, antiserum 1618 directed against the 12-carboxyterminal amino acids of human p53 was used and for western blotting monoclonal antibody $\mathrm{pAb} 1801$, recognising amino acids 45 to 91 of the human p53 amino terminus, was used. (B) The mutation specific antibody pAb240, recognising an epitope located between amino acid 161 and 220 present in human as well as rodent $p 53$, was used for both immunoprecipitation and detection. subsequent western blot analysis with $E C L$-detection. (A) 


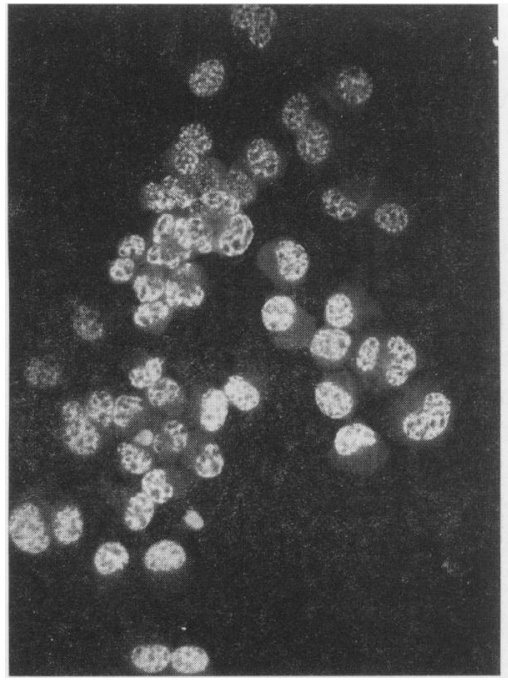

Figure 6: Detection of p53 by immunochemistry. Immunohistochemistry of insulinoma cells (RIN 38) using antibody CM1 (see Fig 4) leading to positive staining of almost all nuclei. Immunofluorescence (left); phase contrast (right), magnification $\times 400$.

murine neuroendocrine cell lines (InR 1G9, RIN 38, AR42J, PC12; Fig 5B and data not shown). Surprisingly, Huh7 taken as a control cell line showed a signal in this immunoprecipitation western blot assay whereas pAb 249 was unable to detect the protein in the radioimmunoprecipitation assay.

Immunohistochemical analysis showed an exclusively nuclear staining 3435 for seven of 12 cell lines tested with the antiserum CM1 against p53 (Fig 6). To test whether the degree of proliferation would correlate with the p53 staining, we performed $\mathrm{Ki}-67$ staining as a marker for cellular proliferation ${ }^{36}$ in parallel. Figure 7 shows two typical immunohistochemical staining results for $\mathrm{Ki}-67$.

Neuroendocrine cell lines InR 1G9 and RIN 38 as well as the ductal cell lines Capan1, Capan2, and Panc1 and the hepatoma cell lines Huh7 and PLC showed a clear nuclear staining for p53 with CM1. In contrast, the human neuroendocrine cell lines Bon and QGP1 as well as the murine AR42J, the ductal DanG and the pheochromocytoma PC12 showed no nuclear staining signals. The immunohistochemical results for Bon, InR
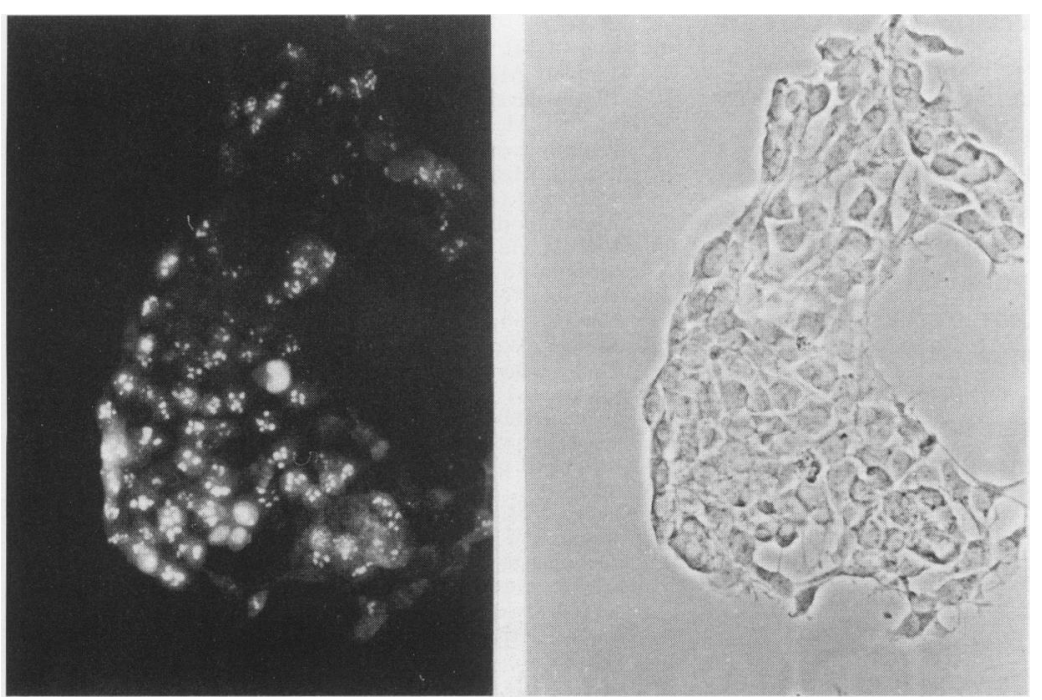

Figure 7: Detection of proliferative activity of pancreatic neuroendocrine cells using antibody Ki-67. Immunofluorescence (left); phase contrast (right); magnification $\times 400$.
1G9, RIN 38, Capan1, Panc1, Huh7, and PLC corresponded with the results obtained by radioimmunoprecipitation. QGP1, AR42J and PC12 showed no immunohistochemical signal despite the precipitable p53 protein. Interestingly, the positive immunohistochemical staining for Capan2 was in contrast with the negative western blot results using pAb 240. DanG was negative both in the western blot analysis and in the immunohistochemical staining. The ductal cell lines as well as the human hepatoma cell lines displayed a $\mathrm{Ki}-67$ LI varying from $35-83 \%$. Three pancreatic neuroendocrine cell lines (Bon, QGP1, and RIN 38) showed a positive nuclear staining with $\mathrm{Ki}-67$ in almost all cells. This is in contrast with the neuroendocrine pancreatic tumours where only a $\mathrm{Ki}-67 \mathrm{LI}$ of below $5 \%$ is seen. Microwave treatment of paraffin wax embedded tissue sections did not increase the immunoreactivity of antibody Mib1. Thus, no correlation between the immunoreactivity for p53 and Ki-67 was seen in neuroendocrine cell lines. Table II summarises the results obtained for the various cell lines studied.

In 19 neuroendocrine tumour tissue specimens no immunoreactivity for $\mathrm{p} 53$ using the polyclonal antiserum CM1 was found. However, human hepatomas $(n=3)$, used as positive controls, showed a strong nuclear immunostaining (data not shown). Sequence analysis was not performed because of the lack of sufficient amounts of human tumour tissue.

\section{Discussion}

This is the first comprehensive study on the expression of the tumour suppressor gene p53 in pancreatic neuroendocrine cancer. Almost all neuroendocrine cell lines examined, contained increased protein and mRNA levels of wild type protein $\mathrm{p} 53$. In contrast with ductal pancreatic cancer cells, known to express mutated p53, deletions or point mutations within the evolutionary highly conserved parts of the coding sequence were not detected in pancreatic neuroendocrine cells. These findings are based on the examination of both pancreatic neuroendocrine tumour cell lines $(n=5)$ and pancreatic neuroendocrine tumour tissues $(n=19)$. At a protein level, increased amounts of p53 were detected in almost all pancreatic neuroendocrine cell lines by western blot analysis, radioimmunoprecipitation and, only in part, by immunohistochemistry. In neuroendocrine tumour tissues, no immunoreactivity for $\mathrm{p} 53$ was seen. At the mRNA level, almost all neuroendocrine tumour cell lines had detectable amounts of p53 specific mRNA. Nucleotide sequence analysis of the evolutionary highly conserved stretch encompassing 5 exons of the coding sequence did not show any deletions or point mutations for pancreatic neuroendocrine cells. In contrast and as already previously shown, several pancreatic ductal ${ }^{14-16}$ and hepatoma ${ }^{37} 38$ cell lines and carcinomas contained point mutations within the evolutionary conserved part of the coding sequence (Fig 1). Until now, detectable p53 at a protein and 
TABLE II Summary of results obtained for various cell lines

\begin{tabular}{|c|c|c|c|c|c|c|c|}
\hline Cell line & Northern & $c D N A$ & $I F(C M 1)$ & $W B$ & $R I P$ & Mutation & IF $(K i-67 L I)$ \\
\hline $\begin{array}{l}\text { Hep G2 } \\
\text { Huh7 } \\
\text { PLC }\end{array}$ & $\begin{array}{l}+ \\
+++ \\
+\end{array}$ & $\begin{array}{l}+ \\
++ \\
+\end{array}$ & $\begin{array}{l}\text { nt } \\
+++ \\
+++\end{array}$ & $\begin{array}{l}\text { nt } \\
+ \\
+\end{array}$ & $\begin{array}{l}\text { nt } \\
+ \\
+\end{array}$ & $\begin{array}{l}\mathrm{nt} \\
\overline{+}\end{array}$ & $\begin{array}{l}\text { nt } \\
57 \\
83\end{array}$ \\
\hline $\begin{array}{l}\text { Bon } \\
\text { QGP1 }\end{array}$ & $\overline{+}+$ & $\begin{array}{l}+ \\
++\end{array}$ & $\begin{array}{l}- \\
-\end{array}$ & $\begin{array}{l}- \\
-\end{array}$ & $\overline{+}$ & $\overline{-}$ & $\begin{array}{r}34 \\
5\end{array}$ \\
\hline $\begin{array}{l}\text { Capan1 } \\
\text { Capan2 } \\
\text { DanG } \\
\text { Panc1 }\end{array}$ & $\begin{array}{l}++ \\
(+) \\
+1 \\
(+) 1\end{array}$ & $\begin{array}{l}++ \\
(+) \\
+ \\
++\end{array}$ & $\begin{array}{l}++ \\
++ \\
- \\
+++\end{array}$ & $\begin{array}{l}+ \\
- \\
- \\
+\end{array}$ & $\begin{array}{l}+2 \\
\mathrm{nt} \\
\mathrm{nt} \\
+\end{array}$ & $\begin{array}{l}+ \\
- \\
+ \\
+\end{array}$ & $\begin{array}{l}35 \\
47 \\
64 \\
\text { nt }\end{array}$ \\
\hline $\begin{array}{l}\text { AR42J` } \\
\text { PC } 12^{\star}\end{array}$ & $\begin{array}{l}+ \\
+\end{array}$ & $\begin{array}{l}+ \\
+\end{array}$ & $\begin{array}{l}- \\
-\end{array}$ & $\begin{array}{l}+ \\
+\end{array}$ & $\begin{array}{l}+ \\
+\end{array}$ & - & - \\
\hline $\begin{array}{l}\text { InR 1G9† } \\
\text { RIN 38* }\end{array}$ & $\begin{array}{l}+ \\
+\end{array}$ & $\begin{array}{l}+ \\
+\end{array}$ & $\begin{array}{l}+++ \\
+++\end{array}$ & $\begin{array}{l}+ \\
+\end{array}$ & $\begin{array}{l}+3 \\
+3\end{array}$ & $\overline{-}$ & $\overline{11}$ \\
\hline
\end{tabular}

Signal intensity: - : negative; $(+)$ : weakly positive; $+:$ positive; ++ : strongly positive; +++ very strongly positive. Northern: northern blot analysis of $20 \mu \mathrm{g}$ total RNA loaded per lane was done with the BamHI-fragment of cDNA clone pC53SN3 for the human cell lines and the Xho I/Sst II-fragment from cDNA clone p1 1-4 for murine cell lines; cDNA: RT-PCR with speciesspecific cDNA-oligodeoxynucleotides (exon 5-8) of $5 \mu \mathrm{g}$ total RNA each; IF (CM1):

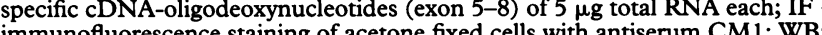
immunofluorescence staining of acetone fixed cells with antiserum CM1; WB:
immunoprecipitation with the C-terminal peptide antiserum 1618 (pAb 240 for murine cell immunoprecipitation with the C-terminal peptide antiserum 1618 (pAb 240 for murine cell
lines respectively) with subsequent ECL detection in combination with western blot; RIP: lines respectively) with subsequent ECL detection in combination with western blot; RIP:
radioimmunoprecipitation of [35S]-metabolically labelled cells with CM1; Mutation: sequence radioimmunoprecipitation of [35S]-metabolically labelled cells with CM1; Mutation: sequence
analysis of genomic or complementary DNA; IF (Ki-67 LI); immunofluorescence microscopy of acetone fixed cells with $\mathrm{Ki}-67$ or Mib-1; the percentage of positively stained cells nuclei is given $-:$ no nuclear stained cells; nt: not tested; ${ }^{\star}$ : rat cell lines; $\dagger$ : hamster cell line; $1:$ slightly larger transcript; 2: higher; 3: lower apparent molecular weight in SDS-PAGE

mRNA level was considered pathognomonic for a deletion or mutation of $\mathrm{p} 53$. Our study shows that an overexpression of p53 can also result, at least in some pancreatic neuroendocrine cancer cells, from post-translational modifications of the protein, as no deletions or mutations were found. This could lead to a changed state of $\mathrm{p} 53$ phosphorylation or to a protein stabilisation similar to a switch between the wild type and mutant conformation of p53 with wild type sequence. ${ }^{39}$ An alternative explanation for our findings could be that the mutation or deletion was missed based on incomplete sequencing. This seems unlikely, however, as all mutations described so far have been only seen in the evolutionary highly conserved region. In addition, several studies on the human hepatoma cell line Huh7 showed that the well known overexpression of p53 could not be accounted for by a deletion or mutation despite sequence analysis of the whole cDNA. Similar to our findings, it was postulated, that post-translational modifications could be responsible for overexpression of $\mathrm{p} 53$. Thus, variable degrees of $\mathrm{p} 53$ overexpression could lead, especially in the case of post-translational modifications, to less pronounced effects on the cell cycle resulting in different forms of pancreatic cancer.

Using immunohistochemistry in combination with antibodies reacting with wild type and mutated p5340 41 we show that only a small portion of the pancreatic neuroendocrine cancer cells contain increased protein levels of $\mathrm{p} 53$. This is particularly relevant for immunohistodiagnostics of human tumour tissue, where tissue is often only available for histochemistry but it escapes biochemical and molecular biological analysis because of insufficient tissue amounts. In addition, PCR analysis of small amounts of tumour tissue is of limited value, because an exact attribution of overexpressed p53 in tissue homogenates is not possible. Thus, our study suggests that lack of p53 immunoreactivity by immunohistochemistry has to be interpreted with care, considering also the negative immunohistochemical results obtained so far. ${ }^{42}$ Interestingly, an overexpression of $\mathrm{p} 53$ seems to correlate with neuroendocrine cellular differentiation - that is, small cell lung cancer with neuroendocrine histology are found to be immunoreactive for p53 by immunohistochemistry in most cases. ${ }^{4344}$ Similarly, we found that the expression of p53 correlated, at least in some cell lines, with an immunoreactivity for the cellular proliferation marker Ki67. In this context, Chaudhry et al ${ }^{45}$ examined a large number of metastatic neuroendocrine tumours of the small intestine as well as pancreas and found that the degree of Ki67 expression corresponded well with a metastatic tumour spread and inversely with a success of an antitumour treatment. Thus, it is tempting to speculate that p53 expression in neuroendocrine pancreatic tumour disease correlates, at least in part, with the state of the neuroendocrine tumour cell differentiation (see also Barbareschi et $a l^{43}$ ). Future studies will have to deal with the identification of components responsible for post-translational modifications during cellular differentiation of neuroendocrine tumour disease. We wish to thank L Schmitt for expert technical assistance and
M E Hearne for synthesising the DNA oligodeoxynucleotides. M E Hearne for synthesising the DNA oligodeoxynucleotides.
We are grateful to H Stein, Department of Pathology, Klinikum We are grateful to H Stein, Department of Pathology, Klinikum
Benjamin Franklin, FU Berlin, Germany, for the gift of Ki-67 monoclonal antibody and to A Teresky and J Martinez from the Department of Molecular Biology, University of Princeton, NJ USA, for supplying the plasmids pC53SN3 and p11-4 respectively. We thank Dr Avril Smith, Klinikum Benjamin Franklin, FU Berlin, Germany, for critically reading the manuscript.

This work was supported by grants from the Deutsche Forschungsgemeinschaft, the Dr Mildred Scheel Stiftung to $\mathrm{KM}$ and $\mathrm{BW}$ as well as the Vaillant-Stiftung, to KM.

1 Morohoshi T, Held G, Klöppel G. Exocrine pancreatic tumors and their histological classification. A study based on 167 autopsy and 97 surgical cases. Histopathology 1983; 7: 645-61.

2 Klöppel G, Fitzgerald PJ. In: Go V, Gardener J, Brooks F, Lebenthal E, DiMagno E, Scheele G, eds. Exocrine pancreas: biology, pathobiology and diseases. New York: Raven, 1986: 649-74.

3 Lemoine N. In: Sluyser M, ed. Molecular biology of cancer genes. Chichester: Ellis Horwood, 1990: 82-118.

4 Hoorens A, Lemoine $\mathrm{N}$, McLellan E, Morohoshi $T$, Kamisawa T, Heitz PU, et al. Pancreatic tumors with acinar cell differentiation: an analysis of cell lineage markers, p53 expression and Ki-ras-expression. Am 7 markers, p53 expression

5 Heitz PU, Klöppel G. Endokrine Tumoren des Pankreas und des Duodenums. Verh Dtsch Ges Pathol 1987; 71: 202-21.

6 Vogelstein B, Fearon E, Hamilton S, Kern S, Preisinger A, Leppert $\mathrm{M}$, et al. Genetic alterations during colorectaltumor development. N Engl f Med 1988; 319: 525-32.

7 Hollstein M, Sidransky D, Vogelstein B, Harris C. p53 mutations in human cancers. Science 1991; 253: 49-53.

8 Milner J, Metcalf E. Cotranslation of activated mutant p53 with wild type drives the wild-type p53 protein into the mutant conformation. Cell 1991; 65: 765-74.

9 Crook T, Tidy JA, Vousden KH. Degradation of $\mathrm{p} 53$ can be targeted by HPV E6 sequences distinct from those targeted by HPV E6 sequences distinct from those 67: $547-56$

10 Crook T, Wrede D, Vousden KH. p53 point mutation in HPV negative human cervical carcinoma cell lines. Oncogene 1991; 6: 873-5.

11 Fakharzahdeh S, Trusko R, George D. Tumorigenic potential associated with enhanced expression of a gene that is amplified in a mouse tumor cell line. EMBO $\mathscr{f} 1991 ; 10$ : 1565-9.

12 Kastan MB, Onyekwere O, Sidransky D, Vogelstein B, Craig RW. Participation of $p 53$ protein in the cellular response to DNA damage. Cancer Res 1991; 51: 6304-11.

13 Shaw P, Bovey R, Tary S, Sahli R, Sordat B, Costa J. Induction of apoptosis by wild-type $\mathrm{p} 53$ in a human colon tumor-derived cell line. Proc Natl Acad Sci USA 1992; 89: 495-8.

14 Barton CM, Staddon SL, Hughes C, Hall P, O'Sullivan C, Klöppel G, et al. Abnormalities of the p 53 tumor suppressor gene in human pancreatic cancer. Br $\mathcal{F}$ Cancer 1991; 64: 1076-82. 
15 Ruggeri B, Zhang SY, Caamano J, DiRado M, Flynn S, Klein-Szanto A. Human pancreatic carcinomas and cel lines reveal frequent and multiple alterations in the p 53 and $\mathrm{Rb}-1$ tumor suppressor genes. Oncogene 1992; 7 : 1503-11.

16 Kalthoff H, Schmiegel W, Roeder C, Kasche D, Schmidt A, Lauer G, et al. p53 and Ki-ras alterations in pancreatic epithelial cell lesions. Oncogene 1993; 8: 289-98.

17 Evers BM, Townsend CM, Upp J, Allen E, Hurlbut S, Kim $S$, et al. Establishment and characterization of human carcinoid in nude mice and effect of various agents on tumor cinoid in nude mice and effect of various age
growth. Gastroenterology 1991; 101: 303-11.

$18 \mathrm{Kaku} \mathrm{M}$, Nishiyama T, Yagawa K, Abe M. Establish-ment of a carcinoembryonic antigen-producing cell line from human pancreatic carcinoma. Gann 1980; 71 596-601.

19 Jessop NW, Hay RJ. Characteristics of two rat pancreatic exocrine cell lines derived from transplantable tumors. In Vitro Cell Dev Biol 1980; 16: 212.

20 Philippe J, Chick WL, Habener J. Multipotential phenotypic expression of genes encoding peptide hormones in rat insulinoma cell lines. $\mathcal{f}$ Clin Invest 1987; 79: 351-8.

21 Takaki R, Ono J, Nakamura M, Yokogawa Y, Kumae S, Hiraoka T, et al. Isolation of glucagon-secreting cell lines by cloning $120-6$.

22 Fogh J, Wright WC, Loveless J. Absence of HeLa cell contamination in 169 cell lines derived from human tumors. $\mathcal{f}$ Natl Cancer Inst 1977; 58: 209-15.

23 Knudson W, Biswas C, Toole B. Interactions between human tumor cells and fibroblasts stimulate hyaluronat synthesis. Proc Natl Acad Sci USA 1984; 81: 6767-71.

24 Lieber M, Mazetta J, Nelson-Rees W, Kaplan M, Todaro G. Establishment of a continuous tumor cell line (Pancl) from a human carcinoma of the exocrine pancreas. Int $\mathcal{f}$ Cancer 1975; 15: 741-7.

25 Aden DP, Fogel A, Plotkin S, Damjanov I, Knowles BB. Controlled synthesis of HBsAg in a differentiated human liver carcinoma-derived cell line. Nature 1979; 282 615-6.

26 Nakabayashi H, Taketa K, Miyano K, Yamane T, Sato J Growth of human hepatoma cell lines with differentiated functions in chemically defined medium. Cancer Res 1992 42: 3858-63.

27 Macnab GM, Alexander JJ, Lecatsas G, Bey E, Urbanowicz J. Hepatitis B surface antigen produced by a human hepatoma cell line. Br f Cancer 1976; 34: 509-15.

28 Greene LA, Tischler AS. Establishment of a noradrenergic clonal line of rat pheochromocytoma cells which respond to nerve growth factor. Proc Natl Acad Sci USA 1976; 73 2424-8.

29 Wiedenmann B, Franke WW, Kuhn C, Moll R, Gould VE. Synaptophysin: a marker protein for neuroendocrine cells and neoplasms. Proc Natl Acad Sci USA 1986; 83: 3500-4.
30 Sambrook J, Maniatis T, Fritsch EF, eds. Molecular cloning. New York: CSH Laboratory Press, 1989.

31 Thein SL. A simplified method of direct sequencing of PCR amplified DNA with Sequenase T7 DNA polymerase. USB Editorial Comments 1989; 4: 8.

32 Tan TH, Wallis J, Levine A. Identification of the p53 domain involved in formation of the Simian virus 40 large $\mathrm{T}$ antigen-p 53 complex. $₹$ Virol $1986 ; 59: 574-83$.

33 Bouwmeester T, Gühmann S, El-Baradi T, Kalkbrenner F, van Wijk I, Milling K, et al. Molecular cloning, expression van Wijk I, Milling $\mathrm{K}$, et al. Molecular cloning, expression proteins in Xenopus. Mech Dev 1992; 37: 57-68

34 Gurney EG, Harrison RO, Fenno J. Monoclonal antibodies against Simian virus $40 \mathrm{~T}$ antigens: evidence for distinct subclasses of large $\mathrm{T}$ antigen and for similarities among non-viral $T$ antigens. $\mathcal{f}$ Virol 1980; 39: 752-63.

35 Dippold WG, Jay G, DeLeo AB, Khoury G, Old LJ. p53 transformation-related protein: detection by monoclonal antibody in mouse and human cells. Proc Natl Acad $\mathrm{Sci}$ USA 1981; 78: 1695-9.

36 Gerdes J, Lemke H, Baisch H, Wacker HH, Schwab U, Stein $\mathrm{H}$. Cell cycle analysis of a cell proliferation-associated human nuclear antigene defined by the monoclonal antibody Ki-67. ₹ Immunol 1984; 133: 1710-5.

37 Hsu I, Metcalf R, Sun T, Welsh J, Wang N, Harris C. Mutational hotspot in the p53 gene in human hepatocellular carcinomas. Nature 1991; 350: 427-8.

38 Bressac B, Kew M, Wands J, Ozturk M. Selective G to T mutations of $\mathrm{p} 53$ gene in hepatocellular carcinoma from Southern Africa. Nature 1991; 350: 429-31.

39 Ullrich SJ, Andersen CW, Mercer WE, Appella E. The p53 tumor suppressor protein, a modulator of cell proliferation. $\mathcal{B}$ Biol Chem 1992; 267: 15259-62.

40 Vojtesek B, Bartek J, Midgley CA, Lane D. An immunohistochemical analysis of the human nuclear phosphoprotein p53. F Immunol Methods 1992; 151: 237-44.

41 Midgley CA, Fisher CJ, Bartek J, Vojtesek B, Lane D, Barnes D. Analysis of p53 expression in human tumors: an antibody raised against human p53 expressed in Escherichia coli. I Cell Sci 1992; 101: 183-9.

42 Yoshimoto K, Iwahana H, Fukada A, Sano T, Saito S, Iakura $M$. Role of 553 mutations in endocrine tumorigenesis: mutation detection by PCR-single strand conformation polymorphism. Cancer Res 1992; 52: 5061-4.

43 Barbareschi M, Girlando S, Mauri F, Arrigoni G, Laurino L, Dalla Palma P, et al. Tumor suppressor gene products, proliferation and differentiation markers in lung neuroendocrine neoplasms. $\mathcal{F}$ Pathol 1992; 166: 343-50.

44 Iggo R, Gatter K, Bartek J, Lane D, Harris A. Increased expression of mutant forms of p53 oncogene in primary expression of mutant forms of p53 onco
lung cancer. Lancet 1990; 335: 675-9.

45 Chaudhry A, Oberg K, Wilander E. A study of biological behaviour based on the expression of a proliferation antigen in neuroendocrine tumors of the digestive system. Tumour Biol 1992; 13: 27-35. 